\title{
The Economy and food security in the Arab World in the Midst of the Corona Crisis
}

\author{
Alexe Eva ${ }^{1}$, Plesoiu Marius Daniel ${ }^{2}$ \\ ${ }^{1} \mathrm{PhD}$ Police Academy Alexandru Ioan Cuza, \\ ${ }^{2} \mathrm{PhD}$ student University of Bucarest. History Faculty \\ E-mail: evaalexee@gmail.com
}

\begin{abstract}
The Corona pandemic as bad as it seen can opens an opportunity for the revival of local agriculture and fill a large part of food shortages in which demography along with other factors plays a major role key by saving the informal Employment on the black market that surround major cities in the Arab World inhabited by tens of millions who went from their countryside to big cities in search for a better life. This in itself constitutes a rare opportunity for all governments in the Arab World helping to stabilize the rural population by making them a source in providing food security, not to add that this would reduce congestion and pollution and considering that the Arab states are, by virtue of their geographical location, among the dry areas with fragile ecosystems we can think of: investing in modern technologies, following the recommendations made by the experts, using rainfall skyscrapers, converting buildings into power generators, applying vertical farming, innovation for afforestation of deserts, taking into account the local experiences, and using biodiversity by cultivating many new plants proven their feasibility.
\end{abstract}

Keywords: Pandemic, Economy, Arab World, Geography, Demography, International and Arab Organizations

\section{Introduction}

Corona returns agriculture to center the of preoccupation and the orientation towards quality crops is a necessity nowadays in the Arab World due to the closure of border crossings avoiding the global pandemic caused by Corona virus and knowing that the success of economies depending on it is indicating that many countries, not only in the Arab World, will revert to the importance of agriculture and pay attention to it as well after the pandemic.

Food security is greatly affected due to mobility restrictions which further reduces the purchasing power and as cases of contagion increase, governments may take a more drastic measures to stop the spread of the virus influencing the global food system. The premise of any measure adopted should be to protect the health and food security of the population in detriment of economic growth. How damaging this approach 
turns out to be for food security will depend on policy responses over the short, medium and long term. In the short term, governments must manage multiple demands such as: responding to the health crisis, managing the shock to the economy and ensuring a smooth functioning of the food system. While the pandemic poses some serious challenges for the food system in the short term, it is also an opportunity to accelerate transformations in the food and agriculture sector and to build its resilience according to the specific of the individual country.

\section{The economy of the Arab region on the ground}

The fatal flaws of the current economic pattern in the midst of the Corona crisis are not only apparent in the shortage of medical protections, but also in the lack of food and other vital products. What is the position of the Arab countries regarding to these flows and do they learn the lessons and work to overcome them?

The changes in our world find their reflection in the dramatic change in our daily lifestyle. Within less than couple of months of the escalation of the Corona crisis, the lives of a third of the universe's populationmore than 2.5 billion people-have become confined between the place of residence, food, beverage stores and household. Overnight, thousands of factories and institutions, along with tens of millions, stopped operating, with losses estimated by the United Nations Conference on Trade and Development at about two trillion dollars. In this situation, e-commerce is flourishing and the status of our virtual lives on the Internet and its multiple means of communication are enhanced like never before.

The Corona pandemic has caused violent economic effects on the Arab economy [1], as the total losses so far have reached about $\$ 1.2$ trillion, amid expectations that about 7.1 million workers will lose their jobs, according to a report issued by the League of Arab States [2], which called for the creation of a crisis fund that can push to alleviate the burden caused by the Corona crises.

In detail, the report indicated that the losses are of 420 billion dollars of market capital, losses of 63 billion dollars of income (gross domestic product) of member states, additional debts amounting to 220 billion dollars, and a loss of 550 million dollars per day of oil revenues, a $\$ 28$ billion decline in exports, a loss of more than $\$ 2$ billion in tariff revenue, and a loss of about 7.1 million jobs in 2020.

According to a preliminary assessment by the International Labor Organization [3], the "Covid-19" epidemic will have a significant impact on labor markets around the world with high unemployment, indicating that financial markets have been negatively and significantly affected by the outbreak of the virus regarding the growing global connection between countries worldwide from the beginning of the millennium so to say the economists is predicting the occurrence of stagflation, that is recession and stagnation in the markets coupled with high levels of inflation.

Oil demand drastically [4] declined following lockdowns and travel restrictions due to the coronavirus pandemic. Initial outlooks and uncertainty surrounding the course of the pandemic led to a disagreement between two of the largest oil producers, Russia and Saudi Arabia in early March. Bilateral talks between global oil producers ended in agreement on April 13th, with promises to cut petroleum output and hopes rising that these might help stabilize the oil price. However, with storage facilities and oil tankers quickly filling up, fears grew over where to store excess oil, leading to benchmark prices seeing record negative prices.

Table 1. An example of some crude oil prices from the Weekly Brent, OPEC basket and WTI crude oil prices from December 30.2019 to September 14, 2020 [5].

\begin{tabular}{|l|c|c|c|}
\hline Date & OPEC Basket & Brent & WTI \\
\hline Sep 14 2020 & 38.96 & 39.61 & 37.26 \\
\hline Aug 10 2020 & 45.01 & 44.99 & 41.01 \\
\hline Jun 15 2020 & 35.09 & 39.72 & 37.12 \\
\hline
\end{tabular}




\begin{tabular}{|l|c|c|c|}
\hline Date & OPEC Basket & Brent & WTI \\
\hline Apr 14 2020 & 19.7 & 29.6 & 20.13 \\
\hline Mar 16 2020 & 30.63 & 30.05 & 28.7 \\
\hline Feb 10 2020 & 54.17 & 53.27 & 49.57 \\
\hline Dec 30 2019 & 68.89 & 68.44 & 61.68 \\
\hline
\end{tabular}

In the world as we saw the health care field and food security are among the branches that are greatly affected by the crisis and the most affected branch by them all of this epidemic in the Arab countries are the oil, tourism and air transportation. This call paying attention to the medical supply industry, communication and information technology as a result of "Corona" crises and last but not least to agriculture and the demographic disposal of the work force across the Arab nations. A report distributed by the General Secretariat of the Arab League [6] calls for the establishment of an Arab Crisis Fund to address Small and Medium Enterprises as a Support Fund, reviewing the conditions necessary to provide financial support to member states, by setting a more flexible conditions and postponing the installments owed by Arab countries during that period by this granting them additional facilities or bearing any fees for this postponement.

Another proposal is the formation of work teams from the relevant joint Arab action institutions and Arab financing institutions whose task is to monitor the impact of the crisis on Arab countries in order to prepare to conduct sectoral studies on the impact of the crisis and to suggest the necessary policies and measures to be taken.

As part of the efforts of the Organization of Islamic Cooperation (OIC) and its relevant organs to contain the effects of the coronavirus pandemic, the Islamic Solidarity Fund (ISF), an OIC subsidiary organ, has disbursed the first payment of its urgent financial grant to the least developed countries among OIC Member States to strengthen their capabilities in the face of the novel coronavirus disease (COVID-19) pandemic, especially in the health sector.

\section{Food Security in the Arab Countries}

It is widely known that the Arab region is facing rising economic, socio-political and environmental challenges, which are impacting food security, first of all for its growing rapidly increasing population [7]. The region [8] is witnessing a rise in the prevalence of undernutrition, overnutrition and nutrient deficiency, classified as the triple burden of malnutrition. Undernourishment is increasing in conflict-plagued and Least Developed Countries, obesity is a high concern in the Gulf Cooperation Council, the Maghreb and the Mashreq countries, while nutrient deficiency is spreading and is especially rife among Arab women.

Generally, we must acknowledge, for first, that the Arab countries [9] do not have sufficient nutrition supplies to meet the needs of there people making them unable to enhance food security for several reasons such as: regional water crises, low rainfall, desertification and dry, weak technical possibilities, the increased dependency on the international markets due to conflicts in the region "oil for food policy" making the region one of the area's most vulnerable to food crisis [10] knowing that the region is the largest food importer, most depend on imports for over half of their needs.

According to the International Monetary Fund [11], regional growth will be around 3 percent negative in 2020. The sharp drop in oil prices and demand hit hard the oil exporters and those dependent on them. All countries worldwide will see a sharp drop in tourism and remittances.

Unemployment and poverty numbers will increase which lead Large countries from the region like Iran and Egypt to buy more wheat as a precaution against social unrest. Morocco will also import more due to climate change which caused a decrease in wheat production in 2020 by over 50 percent. In Yemen [12], 24 million people, 80 percent of the population require humanitarian assistance. 
In Syria [13], 9.3 million people, over half the population, are food insecure, in need of food and livelihood assistance. The new U.S. sanctions and the pandemic will surely increase these numbers. The about 6 million Syrian refugees in Lebanon, Jordan and Turkey those days are dependent on informal employment for daily wages make them vulnerable to closures and economic downturns. In the region there is about a 11 million people [14] internally displaced many of whom are concentrated in Libya, Iraq, Yemen and Syria whom are among the most vulnerable.

In Iraq, the displacement caused by the Islamic State group (ISIS) persists with food aid. For the most of those parts health systems are inadequate to confront a pandemic. Out of the 3 million Palestinians [15] in the West Bank and the 2 million in Gaza, 1.7 million (mostly in Gaza) are food insecure in need for assistance. Further a number of 841,000 people are marginally food secure. The pandemic, its closures, and economic slowdown will lead in worsen the situation.

Lebanon [16] is facing nowadays the biggest economic and political crisis in its history. The financial crisis constitutes in a currency depreciation of 80 percent, a sharp increase in unemployment and poverty and hurdle with food imports. Lebanon's World Food Program Director [17] Abdallah Al-Wardat stated that a one million Lebanese could drop under the food poverty line in 2020. The Interior Ministry says that 60 percent of the population, 2.4 million Lebanese people will drop below the poverty line in 2020. In Libya [18] food security is compromised by conflict and the pandemic, most of the cities facing shortages of basic food items, an increase in prices and supply chain disruptions.

Addressing further the issue of regional Economic migrants [19] we can uphold to a challenge with 35 million people just in the Gulf Cooperation Council countries, Jordan, and Lebanon. Many those days are unemployed and stranded which leads to a cramped living condition and further an invitation to pandemic outbursts so the access to food looms as challenge.

The Gulf states [20], like UAE and Saudi Arabia, was not alone in fearing the disruptions in international supply chains and the risk of governments imposing protectionist measures which could trigger a food crisis especially that the Gulf states and are in no permanent rivers, lakes or minimal rainfall, importing almost $90 \%$ of its consumptions which lead to an upsurge in overseas investments [21] in agriculture.

UAE and Saudi Arabia, the region's political and financial heavyweight, are accelerating their food security programs after the crises revived back memories from 2008 when rice and cereal prices soared. Back then, the wealthy countries rushed to secure overseas farming projects, particularly in African countries, stoking criticism that they were "land grabbing" which lead for many of those projects to fail and since then the Gulf States have been refining their strategies combining more targeted overseas investments with the development of technologies to produce at home.

The Iranian economy [22] is the second largest in the Middle East after the Kingdom of Saudi Arabia. Iran has large reserves of oil and natural gas. The country is largely dependent on revenue from the export of hydrocarbon products. Therefore, its economic growth is directly affected by developments in oil market. In the last 20 years, Iran has tried to pursue an economic policy aimed at diversifying its revenues and reducing its dependence on oil.

Agriculture in Iran accounts for 8 percent of the gross national product. And 19 percent of the workforce is employed in the agricultural sector. Iran, an important agricultural country, is among the world's 20 largest producers of products such as wheat, barley, chicken and potatoes. Both traditional and modern methods are used in the Iranian agricultural system. In addition to small and medium-sized farms, Iran has largescale commercial farms.

According to the Food and Agriculture Organization [23] of the United Nations (FAO), the total cultivated land in Iran is 15 million hectares. And cultivation is more widespread in the western, northwest and northeastern areas of the country. Iran gets $\$ 80$ billion annually from agricultural products, and consumes $\$ 75$ billion worth of agricultural products inside the country. Agricultural production has increased in Iran in recent years. Among the primary products grown there are wheat, barley and corn. 
Wheat is one of the most important grains in Iran. This product constitutes 70 percent of the total grain production in general. Domestic production of wheat covered the entire country's needs in 2006. However, due to the decline in production after the drought that struck the country in 2008, a decision was taken to start again to import wheat. In 2008, a severe cold wave hit the country, followed by a drought, which hit the production of grains, especially wheat and since then Iran was unable to achieve the same level of production.

Table 2. An example of the volume of wheat imports.

\begin{tabular}{|l|c|}
\hline \multicolumn{1}{|c|}{ State [24] } & The volume of wheat imports million tons \\
\hline Egypt & 12,5 \\
\hline Algeria & 7 \\
\hline Morocco & 4,8 \\
\hline Iraq & 3,3 \\
\hline Yemen & 3,3 \\
\hline Saudi Arabia & 3,2 \\
\hline Sudan & 2,7 \\
\hline UAE & 1,8 \\
\hline Tunisia & 1,7 \\
\hline
\end{tabular}

The reality of food security in the Arab World is unstable and may fluctuate [25] from time to time; there is also no self-sufficiency to cover the needs of the people from the Arab states. In addition, food security is connected with the power of water security, as all water resources come from non-Arab states, a shortage that may lead to famines, poverty and divisions.

Therefore, this affects the social security due to the emergence of unemployment and the inability to develop and sustain the general services considered necessary, not to add the infrastructure for the Arab citizens.

The weaknesses of technical abilities [26], rainfalls, desertification, drought are the main reasons for decreasing food security and increasing food subordination or dependency, which become significant in the Arab World, but the Corona crisis might be an opportunity to revive the local agricultural production, along with other medical and essential products analyzing the last successful experiences in Egypt, Tunisia and the Gulf States in growing dates, olives, aloe vera, grains and producing medicines.

Demography [27] may play a major role key by saving the informal Employment on the black market because the slums that surround major cities such as Cairo, Casablanca, Beirut and so on was inhabited by tens of millions who went from their countryside to the big cities in search for a better life. The majority of those people work on the black market having a low wage without unemployment insurance.

There is no doubt that the Corona crisis will cause unemployment to these people more than any other group due to home quarantine and lack of work opportunity. This will push many of them to return to their countryside or to think of returning to it in order to carry out an agricultural or professional economic activity that helps them earn their daily livelihood where the state can be a major contributor by providing them the necessary means to be productive according to the state needs.

\section{Conclusions}

Experiences can be used in all the agriculture from cultivation of legumes and medicinal plants, oil and industrial plants on the basis of exploitering the agricultural lands abandoned by their owners in search of work in major cities such as Cairo, Casablanca, and Beirut or living in the major cities suburbs that lack the most basic elements of a healthy life. 
This constitutes a rare opportunity for all governments in the Arab World helping to stabilize the rural population by making them a source in providing food security. Reducing congestion and pollution in the overcrowded cities is required because nowadays it is widely known that pollution contributes to the spread of diseases and epidemics that cost tens of billions to confront annually worldwide.

As we saw, the Arab states are classified, by virtue of their geographical location, among the dry areas with fragile ecosystems climate which plays an important role in their makeup. The fragility of ecosystems, the prevalence of dry climates, and the scarcity of water have exacerbated desertification in these countries which can be overcome by: investing in modern technologies, taking into account the recommendations made by the experts worldwide and by the International Organizations involved in agriculture like the AOAD [28] and the many UN organizations involved in the field, rainfall using skyscrapers, converting buildings into power generators, applying vertical farming, innovation for afforestation of deserts following the recommendations the local experiences, and using biodiversity by cultivating many new plants that have been identified to have been successfully grown in some Arab countries or other countries having similar desert conditions proven their feasibility in entering the Arab agricultural system, while recognizing the need for research to produce suitable and productive varieties. We can say that the Corona pandemic as bad as it seen can opens an opportunity for the revival of local agriculture and fill a large part of food shortages. The importance of local agriculture resides in saving transportation costs and supplies the consumer with healthy and fresh products benefiting even further from demography itself.

\section{References}

[1] https://reliefweb.int/report/algeria/arab-states-region-covid-19-situation-report-no-6-reporting-period1-31-july-2020.

[2] https://www.oic-oci.org/topic/?t_id=23393\&t_ref=14002\&lan=en.

[3] https://www.ilo.org/global/topics/coronavirus/impacts-and-responses/lang--en/index.htm.

[4] https://www.statista.com/statistics/326017/weekly-crude-oil-prices.

[5] www.statista.com.

[6] https://www.google.com/amp/s/www.alarabiya.net/ar/amp/coronavirus/2020/05/03.

[7] 2017 United Nations Economic and Social Commission for Western Asia (ESCWA) and Food and Agriculture Organization of the United Nations (FAO) publication, "Arab Horizon 2030:" Prospects for Enhancing Food Security in the Arab Region.".

[8] E/ESCWA/SDPD/2019/4/SUMMARY.

[9] The Political Economy of Arab Food Sovereignty, Harrigan J., Palgrave Macmillan, 2014, pp 79101.

[10] Encyclopedia of Food Security and Sustainability, editors in chief Pasquale Ferrante, Elliot M. Berry, Lock L. Anderson, publisher Oliver Walter 2019, pp 25-150.

[11] https://www.imf.org/en/Publications/REO/MECA/Issues/2020/04/15/regional-economic-outlookmiddle-east-central-asia-report.

[12] https://www.fsinplatform.org/sites/default/files/resources/files/GRFC_2020_ONLINE_200420.pdf.

[13] https://www.nytimes.com/2020/06/30/world/europe/syria-aid-refugees-united-nations.html.

[14] https://reliefweb.int/sites/reliefweb.int/files/resources/2019-grid-pressrelease-mena-en.pdf.

[15] https://www.fsinplatform.org/sites/default/files/resources/files/GRFC_2020_ONLINE_200420.pdf.

[16] ashingtonpost.com/gdpr-

consent/?next_url=https $\% 3 \mathrm{a} \% 2 \mathrm{f} \% 2 \mathrm{fwww} . w a s h i n g t o n p o s t . c o m \% 2 \mathrm{fopinions} \% 2 \mathrm{f} 2020 \% 2 \mathrm{f} 05 \% 2 \mathrm{f}$ $20 \% 2$ flebanese-prime-minister-coronavirus-is-pushing-lebanon-toward-major-food-crisis $\% 2 \mathrm{f}$.

[17] http://english.ahram.org.eg/NewsContent/50/1203/370383/AlAhram-Weekly/World/Lebanonthreatened-by-famine.aspx

[18] https://www.who.int/news-room/detail/13-05-2020-joint-statement-on-libya. 
[19] https://www.ilo.org/beirut/areasofwork/labour-migration/lang--en/index.htm.

[20] https://www.ft.com/content/b5d5019d-9335-4cad-a3ad-9752b3938946.

[21] https://www.thenational.ae/business/abu-dhabi-attracts-four-agri-tech-companies-with-100minvestment-1.1003740.

[22] http://millerarabic.com.

[23] http://www.fao.org/3/az571e/AZ571E.pdf.

[24] http://mubasher.aljazeera.net/news.

[25] The Polities of Food - The Global Conflict Between Food Security and Food Sovereignty, William D. Schanbacher, Library of Congress Cataloging in Publication Data 2010, pp 86-101.

[26] Feeding Frenzy, Paul McMahon, Greystone Books, 2014, pp. 15-35.

[27] Agricultural Urbanism, Editors Janine de la Salle, Mark Holland, Green Frigate Books, 2010,p 3584.

[28] Arab Organization for Agricultural Development. 